\title{
The Prognostic Significance of the Neutrophil-to-Lymphocyte Ratio in Patients with Multiple Myeloma: A Pilot Study
}

\section{Multiple Miyelom Hastalarında Nötrofil Lenfosit Oranının Prognostik Önemi}

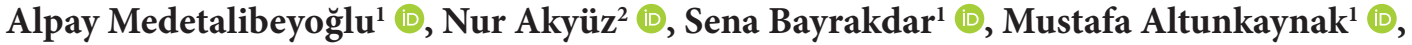 \\ Timur Selçuk Akpınar ${ }^{3}$ (), Cemil Taşçığlu ${ }^{1}$
}

\footnotetext{
Istanbul University, Istanbul Faculty of Medicine Department of Internal Medicine, Istanbul, Turkey

2 University of Vienna, Vienna Faculty of Mediciene, Vienna, Austria

3 Koç Universtiy, Faculty of Medicine, Department
} of Internal Medicine, Istanbul, Turkey

ORCID: A.M. 0000-0002-5829-9186;

N.A. $0000-0001-6462-6828$;

S.B. $0000-0002-4675-185 \mathrm{X}$.

M.A. 0000-0002-7768-2746;

TS.A. 0000-0002-9591-4475;

C.T. 0000-0003-3808-6957

Corresponding author/Sorumlu yazar: Alpay Medetalibeyoğlu,

Istanbul University, Istanbul Faculty of Medicine, Department of Internal Medicine, Istanbul, Turkey E-mail: alibeyoglualpay@gmail.com

Submitted/Geliș tarihi: 22.09.2020 First Revision Received/Ilk revizyon: 20.10 .2020 Last Revision Received/Son revizyon: 22.10.2020 Accepted/Kabul Tarihi: 26.10 .2020

Citation/Atıf: Medetalibeyoglu A, Akyuz N, Bayrakdar S, Altunkaynak M, Akpinar TS, Tascioglu C. The prognostic significance of the neutrophil-to-lymphocyte ratio in patients with multiple myeloma: a pilot study. Sağlık Bilimlerinde İleri Araştırmalar Dergisi 2020; 3(3): 186-194.

https://doi.org/10.26650/JARHS2020-796997

\begin{abstract}
Objective: The neutrophil-to-lymphocyte ratio(NLR) is a biomarker for systematic inflammation. It is also thought that the NLR can be used as a new biomarker by clinicians in predicting the prognosis of patients with multiple myeloma(MM). This study, aimed to retrospectively investigate the prognostic significance of pretreatment NLR in patients with MM, based on the hypothesis that elevated pretreatment NLR is a biomarker indicating worse survival in patients with MM.

Materials and Methods: Patients aged $>18$ years with MM diagnosed, follow-up, and treated between January 2011 and December 2017 in the department of internal and geriatric medicine at Istanbul Faculty of Medicine were enrolled into this study. We retrospectively collected the data of 40 patients from the medical records. The relationship between NLR and baseline characteristics, laboratory parameters, prognosis, and survival outcome was analyzed. Results: The study showed that the mean NLR was 2.84 \pm 2.62 (0.1-14.8) in the whole blood count. No significant correlation was found between NLR and mortality $(\mathrm{p}=0.965)$. A significant relationship was found between higher stage and mortality $(\mathrm{p}=0.035)$. In addition, anemia, low albumin level, and elevated lactate dehydrogenas (LDH) level indicated poor survival time in patients with $\mathrm{MM}(\mathrm{p}=0.022 ; \mathrm{p}=0.031 ; \mathrm{p}=0.023)$.

Conclusion: Our study showed no relationship between NLR and both mortality and overall survival (OS). The above result can be explained by the fact that our study had some limitations such as the use of retrospective data from a single-center and the small sample size.

Keywords: Multiple myeloma, neutrophil-lymphocyte ratio, overall survival
\end{abstract}

ÖZ

Amaç: Nötrofil-lenfosit oranı (NLR), bir sistematik inflamasyon biyobelirtecidir. Multipl miyelomlu (MM) hastalar için de NLR'nin prognozu öngörmede yeni bir biyobelirteç olarak klinisyene yardımcı olabileceği düşünülmektedir. Bu çalışmada, tedavi öncesi NLR'nin MM hastalarında daha kötü bir sağkalım biyobelirteci olduğu hipotezine dayanarak, MM'lu hastalarda tedavi öncesi NLR'nin prognostik önemini retrospektif olarak araştırmayı amaçladık. Gereç ve Yöntem: Çalışmaya, İstanbul Tip Fakültesi İç Hastalıkları ve Geriatri Anabilim Dalı'nda Ocak 2011 - Aralık 2017 tarihleri arasında tanı, takip ve tedavi gören 18 yaş üstü MM hastaları alındı. 40 hastanın verileri tıbbi kayıtlardan retrospektif olarak toplandı. NLR ile temel özellikler, laboratuvar parametreleri, prognoz ve sağkalım arasındaki ilişki analiz edildi.

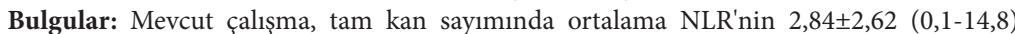
olduğunu gösterdi. NLR ile mortalite arasında anlamlı bir ilişki bulunmadı $(\mathrm{p}=0,965)$ Yüksek evre ile ölüm arasında anlamlı bir ilişki vardır $(\mathrm{p}=0,035)$. Ayrıca anemi, düşük albümin düzeyi ve yüksek laktat dehidrogenaz (LDH) düzeyi MM'lu hastalarda kötü sağkalım süresine işaret ediyordu ( $\mathrm{p}=0,022 ; \mathrm{p}=0,031 ; \mathrm{p}=0,023)$.

Sonuç: Çalışmamız NLR ile mortalite ve genel sağkalım (OS) arasında bir ilişki olmadığını gösterdi. Çalışmamızda NLR ile mortalite ve OS arasında bir ilişkinin olmamasının nedeni, çalışmamızın tek merkezden geriye dönük verilerin toplanması ve küçük örneklem büyüklüğü gibi bazı sınırlılıklara sahip olması olabilir.

Anahtar Kelimeler: Multipl miyelom, nötrofil-lenfosit oranı, genel sağkalım 


\section{INTRODUCTION}

Multiple myeloma (MM) is a plasma cell cancer characterized by the accumulation of neoplastic plasma cells in the bone marrow, which produce excess immunoglobulin. MM is the second most common hematological malignancy that accounts for $1 \%$ of all tumors in adults and approximately $15 \%$ of all hematological malignancies (1). Patients with MM may present clinical manifestations during the course of the disease, including bone pain, renal insufficiency, hypercalcemia, anemia, and recurrent infections (2).

Several researchers have described the absolute lymphocyte count as a surrogate biomarker of tumor-infiltrating lymphocyte, reflecting systemic host immunity, and absolute neutrophil count as the host inflammatory response to cancer. In addition, the absolute counts of inflammation parameters and the NLR have been proposed as a simple and inexpensive marker to assess clinical outcomes in various types of cancers. Recently, the NLR has been shown to be a new independent prognostic factor in patients with $\mathrm{MM}$, and a meaningful relationship has been found between NLR and the accepted prognostic markers (4-6). Further, an elevated NLR may predict worse clinical outcomes in patients with MM (4-7). In this study, we aimed to evaluate the possible association between NLR and clinical parameters, prognosis, and survival in patients with MM.

\section{MATERIALS AND METHODS}

\section{Study Objectives}

Recently, several investigators have suggested that the NLR is an easily available and inexpensive marker for assessing clinical outcomes in MM patients. However, the relationship between NLR and prognosis in patients with MM has not yet been clearly demonstrated. This study aimed to evaluate the prognostic significance of NLR in patients with MM (3-5,7).

\section{Study Population}

Male and female patients aged 26 to 87 years with MM, diagnosed, follow-up, and treated between January 2011 and December 2017 in the department of internal and geriatric medicine at Istanbul Faculty of Medicine were included in this study.

\section{Inclusion and Exclusion Criteria}

Male and female patients older than 18 years at the time of diagnosis with a definite MM were included in the study. Patients without sufficient data in the medical record and regular follow-up were excluded from the study.

\section{Methods}

Since this was a pilot study, no sample size/power calculation was performed. We enrolled 43 patients with MM by a retrospective review of the medical record of patients.

A total of 40 patients with MM were eligible, including 21 female and 19 male patients. The data of these patients were extracted from the hospital automation systems in the department of internal and geriatric medicine at the Istanbul Faculty of Medicine.

The patients were classified according to the International Staging System (ISS) criteria. Dates of death were obtained from the death notification system of the Turkish Statistical Institute. Overall survival (OS) was defined as the period between the date of diagnosis and date of death from any cause.

\section{Statistical Considerations and Data Analysis}

NCSS (Number Cruncher Statistical System) 2007 (Kaysville, Utah, USA) was used for data analysis. Descriptive statistical methods (mean, standard deviation, median, frequency, percentage, minimum and maximum) were used to evaluate the study data. Shapiro Wilk test and graphical analysis were used to determine if the quantitative data were normally distributed. The student $\mathrm{t}$-test was used to make comparisons between two groups of normally distributed quantitative, while the Mann Whitney U test for comparison between two groups of non-normally distributed quantitative variables. Pearson chi-square test and Fisher Freeman Halton test were used to compare the qualitative data. OS was analyzed using Kaplan Meier curves. Comparisons of survival between the different groups were made using the log-rank test. Statistical significance was considered as $\mathrm{p}<0.05$. For visualization of the collected data and resulting prevalence values and relationships, pie charts, bar charts, and tables were used. 


\section{Data Protection}

All patients were coded with a consecutive number and pseudonymized for further evaluation. Only authorized persons had access to the original data.

\section{Risk-Benefit Assessment}

The included patients had no direct benefit from the study. However, since this study was only a retrospective analysis of their data, no patient risk was expected. The only possible risk of the disclosure of sensitive patient data was minimized by the pseudonymization and access restriction.

\section{RESULTS}

\section{Statistical Analysis}

A total of 40 patients with $\mathrm{MM}$, including $21 \mathrm{fe}$ males (52.5\%), and 19 males (47.5\%) were included in the pilot study. The baseline characteristics of the MM patients in this study are shown in Table-1.

Regarding the type of multiple myeloma M protein, the largest group consisted of 7 (20.0\%) with IgG lambda, followed by 5 (14.3\%) patients IgG kappa. In addition, 4 (11.4\%) patients had IgA lambda, 3 (8.6\%) IgA kappa, 8 (22.9\%) light chain kappa, and

Table 1. Distribution of demographic data of patients with MM

\begin{tabular}{|c|c|c|c|c|c|}
\hline \multicolumn{2}{|c|}{ Multiple Myeloma $(n=40)$} & Cases (n) & Percent (\%) & Min-Max (Median) & Mean \pm SD \\
\hline \multirow{3}{*}{ Age (years) } & & & & $26-87(61)$ & $61.20 \pm 11.20$ \\
\hline & \multicolumn{3}{|l|}{ Female } & $43-87(64)$ & $63.4 \pm 11.0$ \\
\hline & \multicolumn{3}{|l|}{ Male } & $26-75(60)$ & $58.9 \pm 11.2$ \\
\hline \multirow{2}{*}{ Gender } & Female & 21 & 52.5 & \multirow{2}{*}{-} & \multirow{2}{*}{-} \\
\hline & Male & 19 & 47.5 & & \\
\hline Subtype $(n=35)$ & $\begin{array}{l}\text { IGA kappa type } \\
\text { IGA lambda type } \\
\text { IGG kappa type } \\
\text { IGG lambda type } \\
\text { IGM kappa type } \\
\text { IGM lambda type } \\
\text { Kappa type } \\
\text { Lambda type } \\
\text { Smoldering type }\end{array}$ & $\begin{array}{l}3 \\
4 \\
5 \\
7 \\
1 \\
1 \\
8 \\
4 \\
2\end{array}$ & $\begin{array}{c}8.6 \\
11.4 \\
14.3 \\
20.0 \\
2.9 \\
2.9 \\
22.9 \\
11.4 \\
5.7\end{array}$ & - & - \\
\hline ISS Staging $(\mathrm{n}=36)$ & $\begin{array}{c}\text { Stage I } \\
\text { Stage II } \\
\text { Stage III }\end{array}$ & $\begin{array}{c}9 \\
7 \\
20\end{array}$ & $\begin{array}{l}25.0 \\
19.4 \\
55.6\end{array}$ & - & - \\
\hline Symptoms & $\begin{array}{c}\text { Weight loss } \\
\text { Weakness } \\
\text { Paleness } \\
\text { Night sweats } \\
\text { Fever } \\
\text { Paresthesia } \\
\text { Bone pain } \\
\text { Shortness of breath } \\
\text { Spinal cord compression }\end{array}$ & $\begin{array}{c}11 \\
22 \\
10 \\
1 \\
9 \\
2 \\
31 \\
2 \\
1 \\
\end{array}$ & $\begin{array}{c}27.5 \\
55.0 \\
25.0 \\
2.5 \\
22.5 \\
5.0 \\
77.5 \\
5 \\
2.5 \\
\end{array}$ & - & - \\
\hline \multirow{2}{*}{$\begin{array}{l}\text { Organomegaly } \\
(\mathrm{n}=39)\end{array}$} & $\begin{array}{l}\text { No } \\
\text { Yes }\end{array}$ & $\begin{array}{l}29 \\
10 \\
\end{array}$ & $\begin{array}{l}74.4 \\
25.6 \\
\end{array}$ & - & - \\
\hline & $\begin{array}{l}\text { Hepatomegaly } \\
\text { Splenomegaly }\end{array}$ & $\begin{array}{c}10 \\
4 \\
\end{array}$ & $\begin{array}{l}25.6 \\
10.3 \\
\end{array}$ & - & - \\
\hline $\begin{array}{l}\text { Palpable Lymphade- } \\
\text { nomegaly }(n=39)\end{array}$ & $\begin{array}{l}\text { No } \\
\text { Yes }\end{array}$ & $\begin{array}{c}37 \\
2 \\
\end{array}$ & $\begin{array}{c}94.9 \\
5.1\end{array}$ & - & - \\
\hline $\begin{array}{l}\text { Pleural Effusion } \\
(\mathrm{n}=39)\end{array}$ & $\begin{array}{l}\text { No } \\
\text { Yes }\end{array}$ & $\begin{array}{c}33 \\
6 \\
\end{array}$ & $\begin{array}{l}84.6 \\
15.4 \\
\end{array}$ & - & - \\
\hline $\begin{array}{l}\text { Extra Plasmacytoma } \\
(\mathrm{n}=39)\end{array}$ & $\begin{array}{l}\text { No } \\
\text { Yes }\end{array}$ & $\begin{array}{c}30 \\
9 \\
\end{array}$ & $\begin{array}{l}77.0 \\
23.0\end{array}$ & - & - \\
\hline Lytic Lesions $(\mathrm{n}=37)$ & $\begin{array}{l}\text { No } \\
\text { Yes }\end{array}$ & $\begin{array}{l}16 \\
21\end{array}$ & $\begin{array}{l}43.2 \\
56.8\end{array}$ & - & - \\
\hline
\end{tabular}


Table 1. Continued

\begin{tabular}{|c|c|c|c|c|c|}
\hline Proteinuria $(\mathrm{n}=31)$ & $\begin{array}{l}\text { No } \\
\text { Yes }\end{array}$ & $\begin{array}{l}14 \\
17 \\
\end{array}$ & $\begin{array}{l}45.2 \\
54.8 \\
\end{array}$ & - & - \\
\hline $\begin{array}{l}\text { Renal Involvement } \\
(\mathrm{n}=40)\end{array}$ & $\begin{array}{l}\text { No } \\
\text { Yes }\end{array}$ & $\begin{array}{c}35 \\
5\end{array}$ & $\begin{array}{l}87.5 \\
12.5\end{array}$ & - & - \\
\hline \multirow{2}{*}{ Hemoglobin (g/dl) } & $>10$ & 15 & 37.5 & \multirow{2}{*}{$5.4-13.9(9.3)$} & \multirow{2}{*}{$9.63 \pm 2.05$} \\
\hline & $\leq 10$ & 25 & 62.5 & & \\
\hline \multirow{3}{*}{$\operatorname{PLT}(\mu \mathrm{L})$} & $>375000$ & 3 & 7.5 & \multirow{3}{*}{$45400-512500(192500)$} & \multirow{3}{*}{$\begin{array}{c}205482.50 \pm \\
94934.06\end{array}$} \\
\hline & $155000-375000$ & 25 & 62.5 & & \\
\hline & $<155000$ & 12 & 30 & & \\
\hline \multirow{2}{*}{$\begin{array}{l}\text { Beta } 2 \text { Microglobulin } \\
(\mathrm{mg} / \mathrm{dl})\end{array}$} & $>2,2$ & 31 & 91.2 & \multirow{2}{*}{$1.7-80.1(5.9)$} & \multirow{2}{*}{$10.21 \pm 14.39$} \\
\hline & $\leq 2,2$ & 3 & 8.8 & & \\
\hline \multirow{2}{*}{ Albumin (g/dl) } & $>3,5$ & 19 & 50 & \multirow{2}{*}{$1.82-5.6(3.54)$} & \multirow{2}{*}{$3.45 \pm 0.80$} \\
\hline & $\leq 3,5$ & 19 & 50 & & \\
\hline \multirow{2}{*}{$\operatorname{ESR}(\mathrm{mm} / \mathrm{h})$} & $>40$ & 33 & 86.8 & \multirow{2}{*}{ 26-155 (92) } & \multirow{2}{*}{$89.45 \pm 34.78$} \\
\hline & $\leq 40$ & 5 & 13.2 & & \\
\hline \multirow{2}{*}{ CRP (mg/l) } & $>5$ & 25 & 67.6 & \multirow{2}{*}{$0-126(8)$} & \multirow{2}{*}{$18.51 \pm 30.07$} \\
\hline & $\leq 5$ & 12 & 32.4 & & \\
\hline \multirow{2}{*}{ LDH (U/L) } & $>250$ & 25 & 62.5 & \multirow{2}{*}{ 113-998 (292.5) } & \multirow{2}{*}{$324.45 \pm 158.28$} \\
\hline & $\leq 250$ & 15 & 37.5 & & \\
\hline \multicolumn{4}{|c|}{ Neutrophil/lymphocytes ratio } & $0.1-14.8(2)$ & $2.84 \pm 2.62$ \\
\hline \multirow{2}{*}{ Survival status } & Alive & 21 & 52.5 & \multirow{2}{*}{-} & \multirow{2}{*}{ - } \\
\hline & Death & 19 & 47.5 & & \\
\hline \multicolumn{4}{|l|}{ Survival time (months) } & $1-73(13)$ & $22.9 \pm 22.0$ \\
\hline
\end{tabular}

4 (11.4\%) light chain lambda. Two patients (5.7\%) had the smoldering type (Figure 1).

The mean age of the patients was $61.20 \pm 11.20$ years, and the age range was between 26 (male) and 87 (female) years. According to sex, the mean age of the female patients was $63.4 \pm 11.0$, and that of the males was $58.9 \pm 11.2$.

Clinically, at the time of diagnosis, 9 (25.0\%) patients were diagnosed as stage I, 7 (19.4\%) patients as stage II, and $20(55.6 \%)$ patients as stage III on the basis of the ISS- staging (Figure 2).

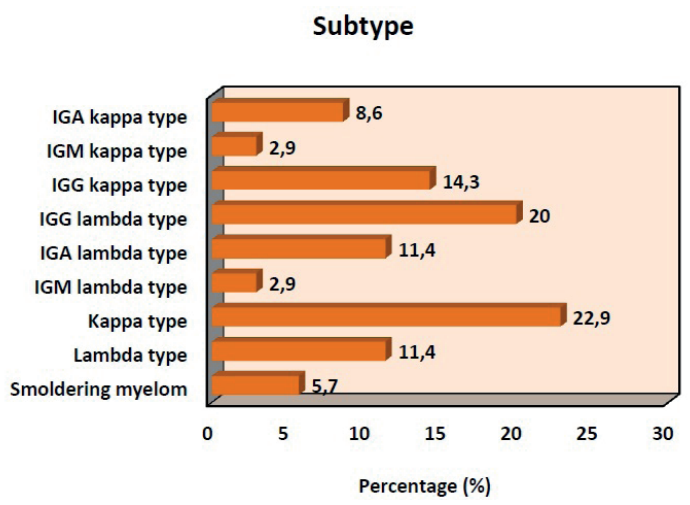

Figure 1. MM population by subtype.
We found that $52.5 \%(n=21)$ of the patients were still alive. The median and mean survival times of the patients were obtained. The follow-up period ranged from 24 to 88 months, and mean survival was $22.9 \pm 22.0$ months (Figure 3).

In the whole blood count, the mean HGB level was 9.63 \pm 2.05 (5.4-13.9) g/dL, mean PLT was 205482.50 \pm 94934.06 (45400-512500) $\mu \mathrm{L}$, mean CRP was $18.51 \pm 30.07(0-126) \mathrm{mg} / \mathrm{L}$, mean ESR was $89.45 \pm 34.78$ (26-155) $\mathrm{mm} / \mathrm{h}$, mean beta- 2 micro-

\section{ISS-Staging}

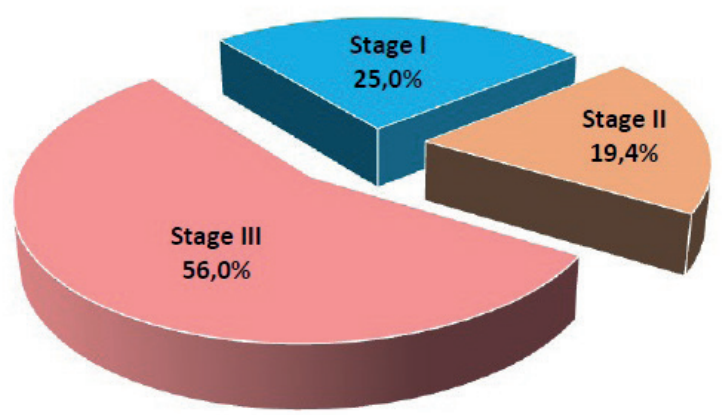

Figure 2. MM patients by ISS-staging. 
globulin was $10.21 \pm 14.39(1.7-80.1) \mathrm{mg} / \mathrm{L}$, mean LDH was $324.45 \pm 158.28$ (113-998) U/L, mean NLR was $2.84 \pm 2.62(0.1-14.8)$ and mean albumin was $3.45 \pm 0.80$

\section{Mortality}

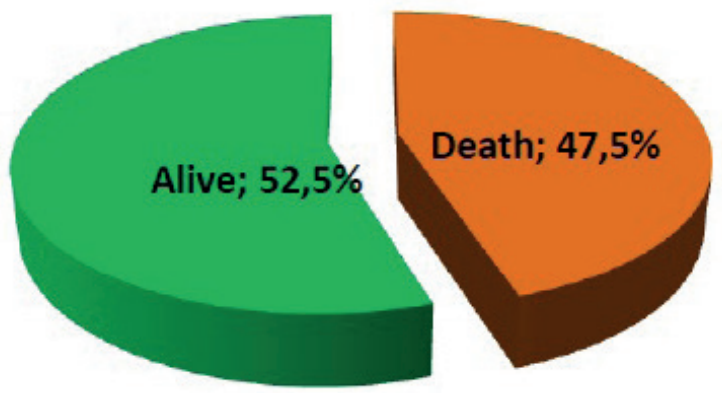

Figure 3. MM population by mortality.
(1.82-5.6) g/dL. Based on the laboratory reference range, 25 (62.5\%) patients had low hemoglobin levels, 12 patients (30.0\%) low PLT levels, and 19 patients (50\%) low albumin levels; CRP was found high in 25 (67.6\%) patients, ESR in $33(86.8 \%)$ patients, LDH levels in $25(62.5 \%)$ patients, and beta- 2 microglobulin in $31(91.2 \%)$ patients.

The demographic assessments of the MM patients by mortality are shown in Table 2 .

Regarding the relationship between mortality and clinical parameters in the patients with MM, no significant correlation was found between age, gender, pathological subtype, and mortality $(\mathrm{p}=0.951$, $\mathrm{p}=0.987, \mathrm{p}=0.622$, respectively).

There was a statistically significant relationship between ISS-staging and mortality $(\mathrm{p}=0.035 ; \mathrm{p}<0.05)$.

Table 2. Demographic assessments of MM patients by mortality

\begin{tabular}{|c|c|c|c|c|}
\hline \multirow{2}{*}{\multicolumn{2}{|c|}{ Multiple Myeloma $(n=40)$}} & \multicolumn{2}{|c|}{ Mortality } & \multirow{3}{*}{$\begin{array}{c}\mathbf{p} \text { values } \\
{ }^{\mathrm{a}} 0.951\end{array}$} \\
\hline & & \multirow{2}{*}{$\begin{array}{c}\text { Death }(\mathbf{n}=19) \\
26-74(63) \\
61.32 \pm 11.46 \\
\end{array}$} & \multirow{2}{*}{$\begin{array}{c}\text { Alive }(\mathbf{n}=\mathbf{2 1}) \\
43-87(60) \\
61.10 \pm 11.23\end{array}$} & \\
\hline Age & $\begin{array}{c}\text { Min-Max(Median) } \\
\text { Mean } \pm \text { SD }\end{array}$ & & & \\
\hline Gender & $\begin{array}{l}\text { Female } \\
\text { Male }\end{array}$ & $\begin{array}{c}10(47.1) \\
9(47.4)\end{array}$ & $\begin{array}{l}11(42.9) \\
10(52.6)\end{array}$ & b0.987 \\
\hline Subtype $(\mathrm{n}=35)$ & $\begin{array}{l}\text { IGA kappa type } \\
\text { IGA lambda type } \\
\text { IGG kappa type } \\
\text { IGG lambda type } \\
\text { IGM kappa type } \\
\text { IGM lambda type } \\
\text { Kappa type } \\
\text { Lambda type } \\
\text { Smoldering type }\end{array}$ & $\begin{array}{c}2(66.7) \\
3(75) \\
3(60) \\
2(28.6) \\
0(0) \\
1(100) \\
3(37.5) \\
2(50) \\
0(0) \\
\end{array}$ & $\begin{array}{c}1(33.3) \\
1(25) \\
2(40) \\
5(71.4) \\
1(100) \\
0(100) \\
5(62.5) \\
2(50) \\
2(100) \\
\end{array}$ & ${ }^{c} 0.622$ \\
\hline ISS Staging $(n=32)$ & $\begin{array}{c}\text { Stage I } \\
\text { Stage II } \\
\text { Stage III }\end{array}$ & $\begin{array}{c}1(11.1) \\
4(51.1) \\
12(60.0)\end{array}$ & $\begin{array}{l}8(88.9) \\
3(42.9) \\
8(40.0)\end{array}$ & ${ }^{\mathrm{c}} 0.035^{\star}$ \\
\hline Albumin g/dl & $\begin{array}{l}>3.5 \\
\leq 3.5\end{array}$ & $\begin{array}{c}7(35.0) \\
12(66.7)\end{array}$ & $\begin{array}{c}13(65.0) \\
6(33.3)\end{array}$ & ${ }^{\mathrm{b}} 0.023^{*}$ \\
\hline HGB (g/dl) & $\begin{array}{c}\text { Min-Max(Median) } \\
\text { Mean } \pm \text { SD }\end{array}$ & $\begin{array}{c}6.1-12.6(8.9) \\
8.9 \pm 1.55 \\
\end{array}$ & $\begin{array}{c}5.4-13.9(10.5) \\
10.33 \pm 2.23 \\
\end{array}$ & ${ }^{\mathrm{a}} 0.022^{\star}$ \\
\hline $\operatorname{PLT}(\mu \mathrm{L})$ & $\begin{array}{c}\text { Min-Max(Median) } \\
\text { Mean } \pm \text { SD }\end{array}$ & $\begin{array}{c}72000-512500(189300) \\
200100 \pm 115483.4\end{array}$ & $\begin{array}{c}45400-397000(200000) \\
210352.4 \pm 74290.8\end{array}$ & ${ }^{\mathrm{d}} 0.336$ \\
\hline NLR & $\begin{array}{c}\text { Min-Max (Median) } \\
\text { Mean } \pm \text { SD }\end{array}$ & $\begin{array}{c}0.4-14.8(2.05) \\
3.06 \pm 3.2\end{array}$ & $\begin{array}{l}0.1-9.5(2) \\
2.64 \pm 2.04\end{array}$ & ${ }^{\mathrm{d}} 0.965$ \\
\hline LDH (U/L) & $\begin{array}{c}\text { Min-Max(Median) } \\
\text { Mean } \pm \text { SD }\end{array}$ & $\begin{array}{c}163-998(315) \\
378.4 \pm 185.9 \\
\end{array}$ & $\begin{array}{c}113-509(240) \\
275.6 \pm 111.7\end{array}$ & ${ }^{\mathrm{d}} 0.031^{\star}$ \\
\hline $\begin{array}{l}\text { Beta } 2 \text { Microglobu- } \\
\text { lin }(\mathrm{mg} / \mathrm{dl})\end{array}$ & $\begin{array}{c}\text { Min-Max(Median) } \\
\text { Mean } \pm \text { SD }\end{array}$ & $\begin{array}{c}2-29(6.7) \\
10.40 \pm 8.71 \\
\end{array}$ & $\begin{array}{c}1.7-80.1(4.5) \\
10.04 \pm 18.3 \\
\end{array}$ & ${ }^{\mathrm{d}} 0.129$ \\
\hline $\operatorname{ESR}(\mathrm{mm} / \mathrm{h})$ & $\begin{array}{c}\text { Min-Max (Median) } \\
\text { Mean } \pm \text { SD }\end{array}$ & $\begin{array}{c}26-155(107.5) \\
95.8 \pm 38.6\end{array}$ & $\begin{array}{c}26-133(84) \\
81.0 \pm 32.6\end{array}$ & ${ }^{\mathrm{d}} 0.230$ \\
\hline CRP (mg/l) & $\begin{array}{c}\text { Min-Max }(\text { Median }) \\
\text { Mean } \pm \text { SD } \\
\end{array}$ & $\begin{array}{c}0-126(9) \\
25.74 \pm 38.5\end{array}$ & $\begin{array}{l}1-203(5) \\
16.5 \pm 28.4\end{array}$ & ${ }^{\mathrm{d}} 0.378$ \\
\hline
\end{tabular}

${ }^{\mathrm{a} S t u d e n t} \mathrm{t}$ Test, ${ }^{\mathrm{b}}$ Pearson Chi-Square Test, ${ }^{\mathrm{c}}$ Fisher Freeman Halton Test ${ }^{\mathrm{d}}$ Mann Whitney U Test, ${ }^{*} \mathrm{p}<0.05$ 
In addition, the frequency of ISS-Stage III was higher in dead patients (60.0\%) compared to patients who were still alive (40.0\%) (Figure 4).

Regarding the relationship between mortality and laboratory parameters in the patients with $\mathrm{MM}$, there was a statistically significant relationship between $\mathrm{HGB}$, $\mathrm{LDH}$, and albumin measurements and mortality ( $\mathrm{p}=0.022, \mathrm{p}<0.05 ; \mathrm{p}=0.031, \mathrm{p}<0.05 ; \mathrm{p}=0.023, \mathrm{p}<0.05)$.

The mean HGB concentration was $8.9 \pm 1.55$ (6.112.6) $\mathrm{g} / \mathrm{dL}$ in the death patients and $10.33 \pm 2.23$ (5.4-13.9) $\mathrm{g} / \mathrm{dL}$ in patients who are still alive; the HBG levels of the dead MM patients were found to be lower than those of the patients who were still alive (Figure 5).

The mean LDH level was 378.4 \pm 185.9 (163-998) $\mathrm{U} / \mathrm{L}$ in the death patients and 275.6 \pm 111.7 (113-509) $\mathrm{U} / \mathrm{L}$ in patients who were still alive; the LDH levels of the dead MM patients were higher than those of the patients who were still alive (Figure 6)

The patients were divided into two categories as $\geq 3.5 \mathrm{~g} / \mathrm{dL}$ albumin level and $<3.5 \mathrm{~g} / \mathrm{dL}$ albumin lev$\mathrm{el}$, and the mortality rate in patients with albumin $<3.5 \mathrm{~g} / \mathrm{dL}$ (66.7\%) was found to be higher compared to patients with albumin $\geq 3.5 \mathrm{~g} / \mathrm{dL}$ (35\%) (Figure 7).

\section{ISS-Staging}

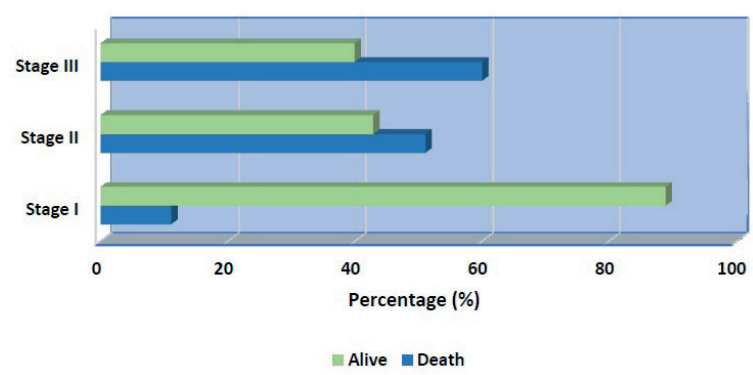

Figure 4. The ISS-Staging distributions of MM patients by mortality.

HGB

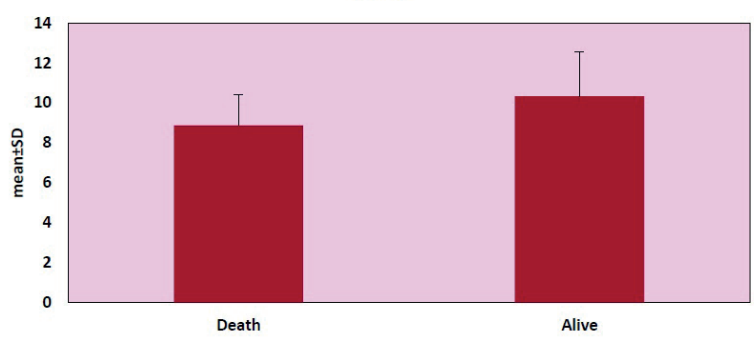

Figure 5. The HGB distributions of MM patients by mortality.
No significant correlation was found between PLT, beta- 2 microglobulin, ESR, CRP levels, NLR, and mortality $(\mathrm{p}=0.336, \mathrm{p}=0.129, \mathrm{p}=0.230, \mathrm{p}=0.378$, $\mathrm{p}=0.965$, respectively). It is noteworthy that the ESR measurements of the dead patients were higher than those of the patients who were still alive ( $p>0.05)$.

We found a higher OS in patients with albumin $\geq 3.5 \mathrm{~g} / \mathrm{dL}$ compared to patients with albumin $<3.5$ $\mathrm{g} / \mathrm{dL}(\mathrm{p}=0.028, \mathrm{p}<0.05)$ (Figure 8).

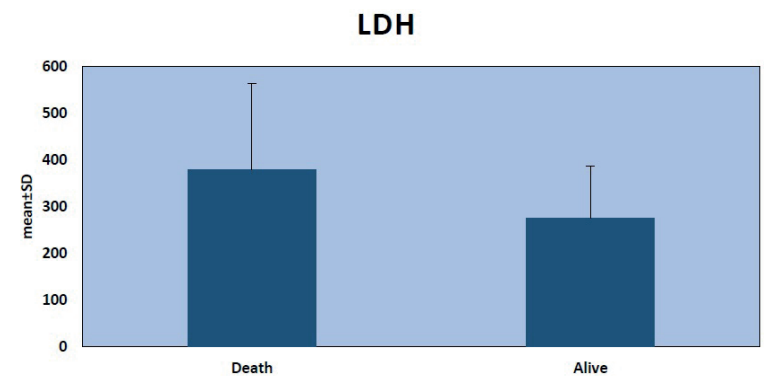

Figure 6. The LDH distributions of $\mathrm{MM}$ patients by mortality.

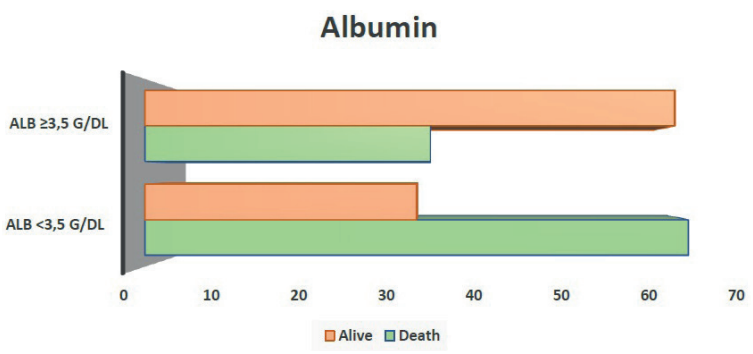

Figure 7. The albumin distributions of MM patients by mortality.

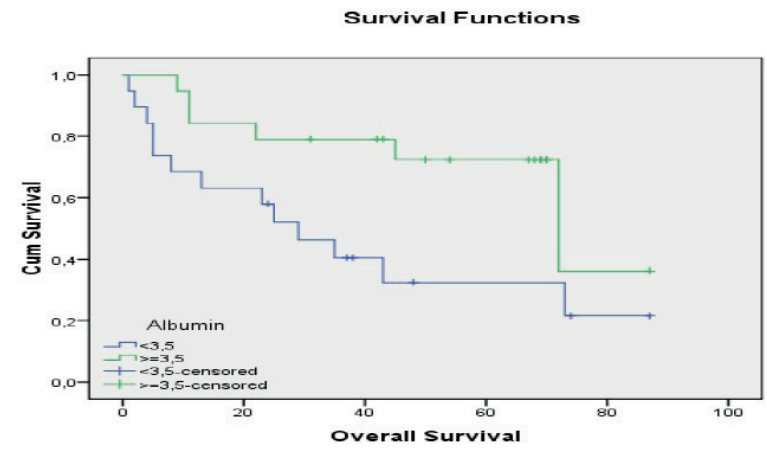

Figure 8. Survival rate correlation with albumin level.

\section{DISCUSSION}

MM accounts for $1 \%$ of all cancers and approximately $15 \%$ of hematological cancers. Thus, it is the second most common hematological cancer. MM 
occurs more frequently in men than in women, and the cause is unknown (3). In our study, $47.5 \%$ males and $52.5 \%$ females were diagnosed with MM. The male-to-female ratio was found to be 0.90 , and therefore, the ratio in our study was not consistent with the worldwide literature. The median age at diagnosis is 65 years in Europe, and 69 years in the USA, and it is rarely diagnosed under 40 years $(3,10)$. The median age in our study was $61.2 \mathrm{yr}$. Accordingly, our population was still younger compared with the literature. We found no significant association between age and survival.

The previous studies reported that gender had no statistically significant effect on prognosis and OS in MM patients $(8,13,16,17)$. In our study, similar to the literature, no significant correlation was found between gender and both mortality and OS.

Studies have demonstrated that higher stages of the disease tend to correlate with a poor prognosis $(6,8,9,12)$. In our study, consistent with the previous results, there was a statistically significant correlation between the ISS stage and mortality.

According to the study by Zhou et al. the IgD subtype was shown to be an independent risk factor for prognosis, and it was associated with a poor OS (11). In our study, the majority of the study population also had IgG.

Pleural effusion (PE) is a poor prognosis factor in patients with MM. In our study, the incidence of $\mathrm{PE}$ was as high as $15.4 \%$. The reason for the high incidence of PE in our study may due to the small number of cases.

Osteolytic lesions are one of the most common clinical manifestations of MM. In our study, more than half of the patients had bone lesions at the time of diagnosis.

Anemia is considered to be a poor prognostic factor in MM patients (14).In our study, the mean $\mathrm{Hb}$ concentration was 9.63 , and $62.5 \%$ of patients had $<10 \mathrm{mg} / \mathrm{dL}$ HGB level. Our findings were similar to those in the literature. Anemia in MM patients was associated with a worse outcome in the literature $(13,14,20,21)$. In our study, similar to the literature, there was a statistically significant relationship between hemoglobin level and mortality.
Recent studies showed that a decreased PLT level predicts poor prognosis in MM patients $(6,8,9,22)$. In our study, no significant correlation was found between PLT level and both mortality and OS in patients with MM. However, similar to our study, some studies reported no significant relationship between the PLT level and OS $(5,15)$.

Recently, it has been suggested that the NLR can be used to predict prognosis in patients with MM. It has been reported in previous publications that an elevated NLR was associated with shortened OS in MM patients (4-6,23). In our study, there was no relationship between the NLR and both mortality and OS in patients with MM. However, similar to our study, no significant correlation between NLR and mortality and OS was demonstrated in other studies $(9,15)$.

Serum beta- 2 microglobulin and LDH are the most important markers for estimating the proliferative activity and invasive potential of MM (16). In our study, a high level of beta- 2 microglobulin was found in $91.2 \%$ patients, while $62.5 \%$ of patients in our study had a high LDH level. We found no significant correlation between beta-2 microglobulin level and mortality and OS. The elevated LDH level has been frequently shown to indicate an unfavorable prognosis $(8,17,18,19,23)$. Similar to previous studies, our study found a statistically significant relationship between LDH level and mortality.

A relationship between low albumin level and poor outcomes of MM patients has been demonstrated in the literature $(8,24,25,26)$. In addition, similar to the literature, our study found a statistically significant relationship between albumin level and both mortality and OS, and the patients with low albumin levels had a poor survival.

\section{CONCLUSION}

Our study retrospectively evaluated the correlation between clinical and laboratory parameters and mortality and OS in patients with MM. The current study showed that there is a significant relationship between higher stages of the disease and mortality. In addition, anemia, low albumin levels, and elevated LDH levels indicated poor survival time in patients with MM. 
In summary, our study showed no relation between NLR and both mortality and OS. The reason for this could be that our study had some limitations such as the use of retrospective data from a single-center and the small sample size.

Hakem Değerlendirmesi: Dış bağımsız.

Peer Review: Externally peer-reviewed.

Etik Komite Onayı: Bu calışma icin etik komite onayı İstanbul Universitesi İstanbul Tip Fakultesi Etik Kurulu'ndan alınmıştır. (20.12.2018 tarihli, 1743 sayıl1).

Ethics Committee Approval: This study was approved by the Ethical Committee of the Istanbul University Istanbul Faculty of Medicine (Date: 20.12.2018, Number: 1743).

Bilgilendirilmiş Onam: Katılımcılardan bilgilendirilmiş onam alınmıştır.

Informed Consent: Written consent was obtained from the participants.

Yazar Katkıları: Çalışma Konsepti/Tasarım- C.T., T.S.A., A.M., M.A.; Veri Toplama- N.A., S.B.; Veri Analizi/Yorumlama- A.M., M.A., N.A.; Yazı TaslağıA.M., N.A., S.B.; İçeriğin Eleştirel İncelemesi- C.T., T.S.A., M.A.; Son Onay ve Sorumluluk- A.M., N.A., S.B., M.A., T.S.A., C.T.; Malzeme ve Teknik DestekN.A., S.B.; Süpervizyon- C.T., T.S.A.

Author Contributions: Conception/Design of Study- C.T., T.S.A., A.M., M.A.; Data AcquisitionN.A., S.B.; Data Analysis/Interpretation- A.M., M.A., N.A.; Drafting Manuscript- A.M., N.A., S.B.; Critical Revision of Manuscript- C.T., T.S.A., M.A.; Final Approval and Accountability- A.M., N.A., S.B., M.A., T.S.A., C.T.; Technical or Material Support- N.A., S.B.; Supervision- C.T., T.S.A.

Çıkar Çatışması: Yazarlar çıkar çatışması beyan etmemişlerdir

Conflict of Interest: Authors declared no conflict of interest.

Finansal Destek: Yazarlar finansal destek beyan etmemişlerdir.

Financial Disclosure: Authors declared no financial support.

\section{REFERENCES}

1. Spicka I. Advances in multiple myeloma therapy during two past decades. Comput Struct Biotechnol J 2014;10(16):38-40.

2. Hameed A, Brady JJ, Dowling P, Clynes M, O'Gorman P. Bone disease in multiple myeloma: pathophysiology and management. Cancer Growth Metastasis 2014;7:33-42.

3. Jameson JL, Kasper DL, Hauser SL, Longo DL, Fauci AS, Loscalzo J, editors. Harrison's principles of internal medicine 2018. Published by McGraw Hill Medical Books.

4. Kelkitli E, Atay H, Çilingir F, Güler N, Terzi Y, Özatlı D, et al. Predicting survival for multiple myeloma patients using baseline neutrophil/ lymphocyte ratio. Ann Hematol 2014;93(5):841-6.

5. Wongrakpanich S, George G, Chaiwatcharayut W, Biso S, Candelario N, Mittal V, et al. The Prognostic Significance of Neutrophil-toLymphocyte and Platelet-to-Lymphocyte Ratios in Patients With Multiple Myeloma. J Clin Lab Anal 2016;30(6):1208-13.

6. Shi L, Qin X, Wang H, Xia Y, Li Y, Chen X, et al. Elevated neutrophil-to-lymphocyte ratio and monocyte-to-lymphocyte ratio and decreased platelet-to-lymphocyte ratio are associated with poor prognosis in multiple myeloma. Oncotarget 2017;8(12):18792-801.

7. Rajkumar SV, Dimopoulos MA, Palumbo A, Blade J, Merlini G, Mateos M-V, et al. International Myeloma Working Group updated criteria for the diagnosis of multiple myeloma. Lancet Oncol 2014;15(12):e538-e48.

8. Greipp PR, Miguel JS, Durie BG, Crowley JJ, Barlogie B, Bladé J, et al. International staging system for multiple myeloma. J Clin Oncol 2005;23(15):3412-20.

9. Solmaz S, Uzun O, Acar C, Sevindik O, Piskin $\mathrm{O}$, Ozsan $\mathrm{H}$, et al. Is the platelet-to-lymphocyte ratio a new prognostic marker in multiple myeloma?. J Lab Physicians 2018;10(4):363-9.

10. Willenbacher E, Weger R, Rochau U, Siebert U, Willenbacher W. Real-World Use of 3rd Line Therapy for Multiple Myeloma in Austria: An Austrian Myeloma Registry (AMR) Analysis of the Therapeutic Landscape and Clinical Outcomes prior to the Use of Next 
Generation Myeloma Therapeutics. PLoS One 2016;11(3):e0147381.

11. Zhao Q, Li F, Song P, Zhou X, An Z, Mei J, et al. Poor outcomes of immunoglobulin D multiple myeloma patients in the era of novel agents: a single-center experience. Cancer Commun (Lond) 2019;39(1):51.

12. Andriandi, Kamal AF. Survival rate of multiple myeloma patients in Indonesia: A retrospective study in multiple myeloma at a single institution. Ann Med Surg (Lond.) (2019). 2019;41:11-5.

13. Acquah ME, Hsing AW, McGuire V, Wang S, Birmann B, Dei-Adomakoh Y. Presentation and survival of multiple myeloma patients in Ghana: a review of 169 cases. Ghana Med J 2019;53(1):52-8.

14. Birgegard G, Gascon P, Ludwig H. Evaluation of Anaemia İn Patients With Multiple Myeloma And Lymphoma: Findings of the European Cancer Anaemia Survey. Eur J Haematol 2006;77(5):378-86.

15. Atallah JP, Azab B, Vivekanandarajah A, Naboush A, Sater HA, Farhan M, et al. Elevated Neutrophil: Lymphocyte Ratio Does Not Predict Survival In Multiple Myeloma Patients. Blood 2013;122(21):5336.

16. Rossi D, Fangazio M, De Paoli L, Puma A, Riccomagno P, Pinto V, et al. Beta-2microglobulin is an independent predictor of progression in asymptomatic multiple myeloma. Cancer 2010;116(9):2188-200.

17. Gu Y, Yuan Y-H, Xu J, Shi Q-L, Qu X-Y, Guo R, et al. High serum lactate dehydrogenase predicts an unfavorable outcome in Chinese elderly patients with multiple myeloma. Oncotarget 2017;8(29):48350-61.

18. Patel KK, Orlowski RZ, Weber DM, Wang M, Thomas SK, Shah JJ, et al. Prognostic value of serum lactate dehydrogenase in symptomatic multiple myeloma. J Clin Oncol 2012.
19. Gkotzamanidou M, Kastritis E, Gavriatopoulou MRMMM, Nikitas N, Gika D, Mparmparousi D, et al. Increased serum lactate dehydrongenase should be included among the variables that define very-high-risk multiple myeloma. Clin Lymphoma Myeloma Leuk 2011;11(5):409-13.

20. Caro JJ, Salas M, Ward A, Goss GJC. Anemia as an independent prognostic factor for survival in patients with cancer: a systematic, quantitative review. Cancer 2001;91(12):2214-21.

21. San Miguel JF, Sanchez J, Gonzalez MJBjoc. Prognostic factors and classification in multiple myeloma. Br J Cancer 1989;59(1):113.

22. Jung S-H, Kim JS, Lee WS, Oh SJ, Ahn J-S, Yang D-H, et al. Prognostic value of the inverse platelet to lymphocyte ratio (iPLR) in patients with multiple myeloma who were treated up front with a novel agent-containing regimen. Ann Hematol 2016;95(1):55-61.

23. Zhou X, Wang J, Xia J, Cheng F, Mao J, Zhu J, et al. Evaluation of neutrophil-to-lymphocyte ratio in newly diagnosed patients receiving bortezomib-based therapy for multiple myeloma. Cancer Biomark 2018;22(1):43-8.

24. Mihou D, Katodritou E, Zervas KJH. Multiple myeloma staging based on the combination of beta-2-microglobulin and albumin: the role of albumin in the model. Hematology 2007;12(6):527-31.

25. Scudla V, Budikova M, Fischerova E, Zadrazil J, Indrak K. Stratification of multiple myeloma according to serum beta 2-microglobulin and serum albumin levels. Acta Univ Palacki Olomuc Fac Med 1991;130:201-12.

26. Bataille R, Durie B, Grenier J, Sany JJJoCO. Prognostic factors and staging in multiple myeloma: a reappraisal. J Clin Oncol 1986;4(1):80-7. 